\title{
The gene cluster for chloramphenicol biosynthesis in Streptomyces venezuelae ISP5230 includes novel shikimate pathway homologues and a monomodular non- ribosomal peptide synthetase gene
}

\author{
J. He, $†$ N. Magarvey, $\neq$ M. Piraee and L. C. Vining \\ Author for correspondence: L. C. Vining. Tel: +1 902494 2040. Fax: +1 9024943736. \\ e-mail: Leo.Vining@Dal.Ca
}

Department of Biology, Dalhousie University, Halifax, Nova Scotia, Canada B3H 4J1
Regions of the Streptomyces venezuelae ISP5230 chromosome flanking pabAB, an amino-deoxychorismate synthase gene needed for chloramphenicol $(\mathrm{Cm})$ production, were examined for involvement in biosynthesis of the antibiotic. Three of four ORFs in the sequence downstream of pabAB resembled genes involved in the shikimate pathway. BLASTX searches of GenBank showed that the deduced amino acid sequences of ORF3 and ORF4 were similar to proteins encoded by monofunctional genes for chorismate mutase and prephenate dehydrogenase, respectively, while the sequence of the ORF5 product resembled deoxy-arabino-heptulosonate-7-phosphate (DAHP) synthase, the enzyme that initiates the shikimate pathway. A relationship to $\mathrm{Cm}$ biosynthesis was indicated by sequence similarities between the ORF6 product and membrane proteins associated with $\mathrm{Cm}$ export. BLASTX searches of GenBank for matches with the translated sequence of ORF1 in chromosomal DNA immediately upstream of pabAB did not detect products relevant to $\mathrm{Cm}$ biosynthesis. However, the presence of $\mathrm{Cm}$ biosynthesis genes in a $7.5 \mathrm{~kb}$ segment of the chromosome beyond ORF1 was inferred when conjugal transfer of the DNA into a blocked $S$. venezuelae mutant restored $\mathrm{Cm}$ production. Deletions in the $7.5 \mathrm{~kb}$ segment of the wild-type chromosome eliminated $\mathrm{Cm}$ production, confirming the presence of $\mathrm{Cm}$ biosynthesis genes in this region. Sequencing and analysis located five ORFs, one of which (ORF8) was deduced from BLAST searches of GenBank, and from characteristic motifs detected in alignments of its deduced amino acid sequence, to be a monomodular nonribosomal peptide synthetase. GenBank searches did not identify ORF7, but matched the translated sequences of ORFs 9,10 and 11 with short-chain ketoreductases, the ATP-binding cassettes of ABC transporters, and coenzyme A ligases, respectively. As has been shown for ORF2, disrupting ORF3, ORF7, ORF8 or ORF9 blocked Cm production.

Keywords: $p$-aminophenylalanine, gene disruption, mutant complementation, sequence analysis

† Present address: Shenyang Pharmaceutical University, Shenyang, P.R. China.

¥Present address: Department of Natural Products Microbiology, Wyeth Ayerst Research, 401 N. Middletown Rd, Pearl River, NY 10965, USA.

Abbreviations: ADC, 4-amino-4-deoxychorismate; Am, apramycin; Cm, chloramphenicol; DAHP, deoxy-arabino-heptulosonate-7-phosphate; Km, kanamycin; NRPS, non-ribosomal peptide synthetase; PABA, p-aminobenzoic acid; PAPA, p-aminophenylalanine; PAPS, $p$-aminophenylserine; Ts, thiostrepton.

The GenBank accession number for the sequence reported in this paper is AF262220. 


\section{INTRODUCTION}

Chloramphenicol (Cm; Fig. 1) is produced by the filamentous Gram-positive soil bacterium Streptomyces venezuelae and certain other actinomycetes. The phenylpropanoid moiety of $\mathrm{Cm}$ has its origins in the general shikimate pathway for assembling aromatic metabolites (Vining \& Westlake, 1984). The route to Cm branches at chorismic acid to generate $p$-aminophenylalanine (PAPA), which serves as a precursor of the $p$ nitrophenylserinol component of the antibiotic (Teng et al., 1985). Incorporation of isotopically labelled Cm precursors and characterization of intermediates accumulated by $S$. venezuelae mutants blocked in $\mathrm{Cm}$ biosynthesis have suggested a sequence of reactions involving $p$-aminophenylserine (PAPS) and $\mathrm{N}$-dichloroacetyl $p$-aminophenylserinol (see Fig. 1 ) through which PAPA is converted to the $p$-nitrophenylserinol derivative (Vining \& Stuttard, 1994). Genes associated with mutational loss of $\mathrm{Cm}$ biosynthesis have been mapped by analysing conjugational crosses and cotransduction frequencies in S. venezuelae ISP5230 and shown to constitute a $\mathrm{Cm}$ biosynthesis cluster (Doull et al., 1986; Vats et al., 1987). Mapping data for all blocked $\mathrm{Cm}$ producers in which the mutation has been located have placed the cluster at approximately 2 o'clock on a circular S. venezuelae ISP5230 chromosome. However, relatively little is known of the molecular genetics of $\mathrm{Cm}$ production and until now no gene in the mapped cluster has been isolated.

In an initial approach to cloning the genes, Aidoo et al.
(1990) transformed S. venezuelae cml-1, a mutant of $S$. venezuelae ISP5230 blocked in Cm biosynthesis at a step preceding PAPA, with a plasmid carrying wild-type genomic DNA fragments that had been shown to complement an auxotrophic Streptomyces lividans mutant with a requirement for $p$-aminobenzoic acid (PABA). The inability of transformants to produce $\mathrm{Cm}$ implied that the DNA fragment supporting PABA synthesis did not support PAPA synthesis and suggested a distinction between primary and secondary metabolic reactions generating the intermediate 4-amino-4-deoxychorismic acid (ADC; Fig. 2) common to the PABA and PAPA pathways. In subsequent work, Brown et al. (1996) cloned and sequenced an S. venezuelae DNA fragment that contained a distinctive, fused ADC synthase gene ( $p a b A B)$, disruption of which created only a marginal growth dependence in $S$. venezuelae for exogenous $\mathrm{PABA}$, but severely reduced $\mathrm{Cm}$ production. Thus $p a b A B$, although not originally included in the genetically mapped cluster of $\mathrm{cml}$ genes, appeared to have a pivotal role in $\mathrm{Cm}$ biosynthesis. The role of the fused $p a b A B$ contrasts with that of the discrete $p a b A$ and pabB genes of E. coli and Bacillus subtilis (Slock et al., 1990), where the products serve as components of an ADC synthase that, by associating with PabC (Nichols et al., 1989), form the PABA synthase complex functioning in primary metabolism to generate PABA for incorporation into folic acid derivatives. The results obtained with the fused gene set in S. venezuelae implicate an alternative secondary metabolic role of ADC synthase. In association with ADC mutase, the

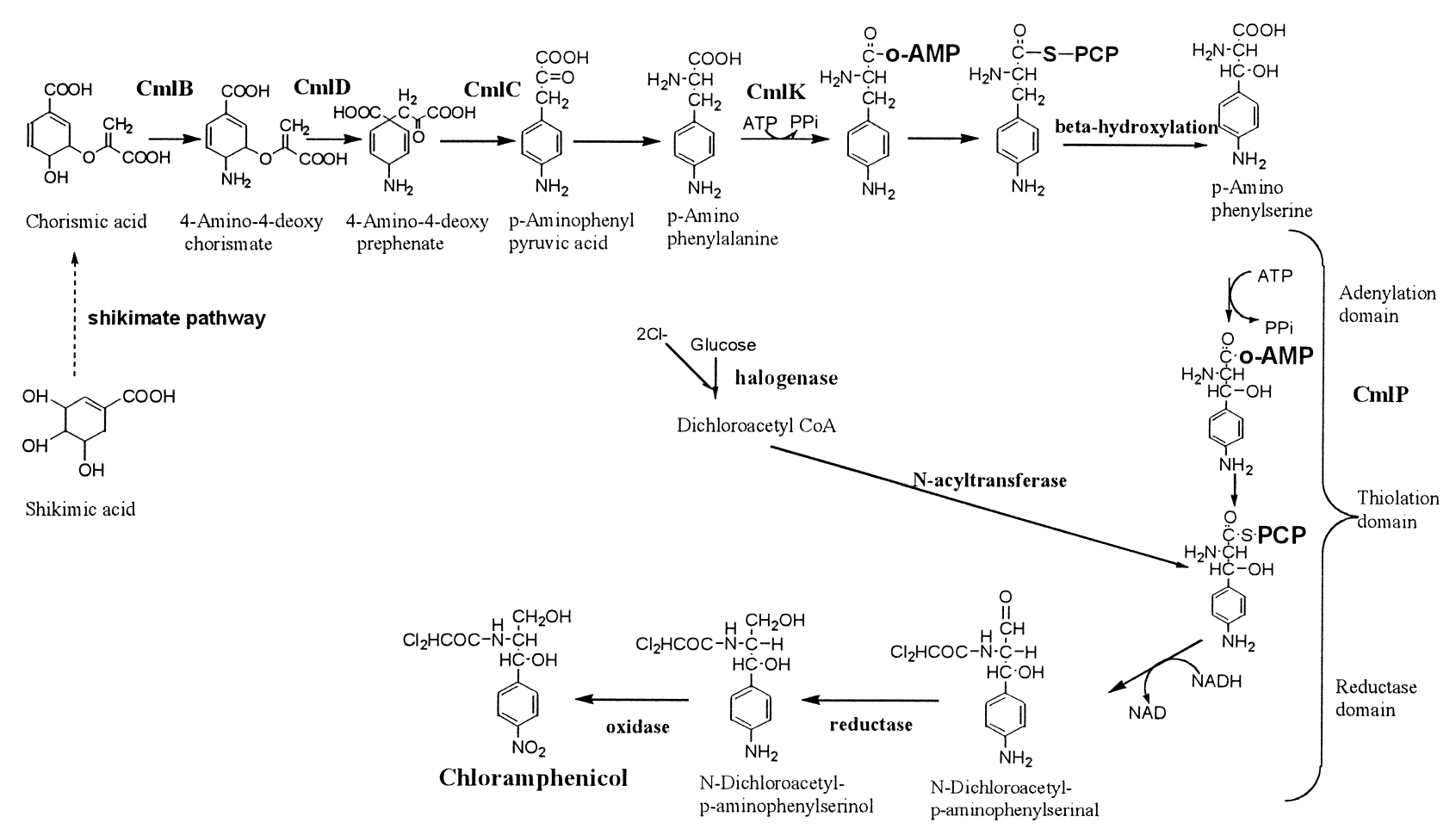

Fig. 1. Scheme showing potential roles for $\mathrm{Cm}$ biosynthesis genes referred to in this research. 


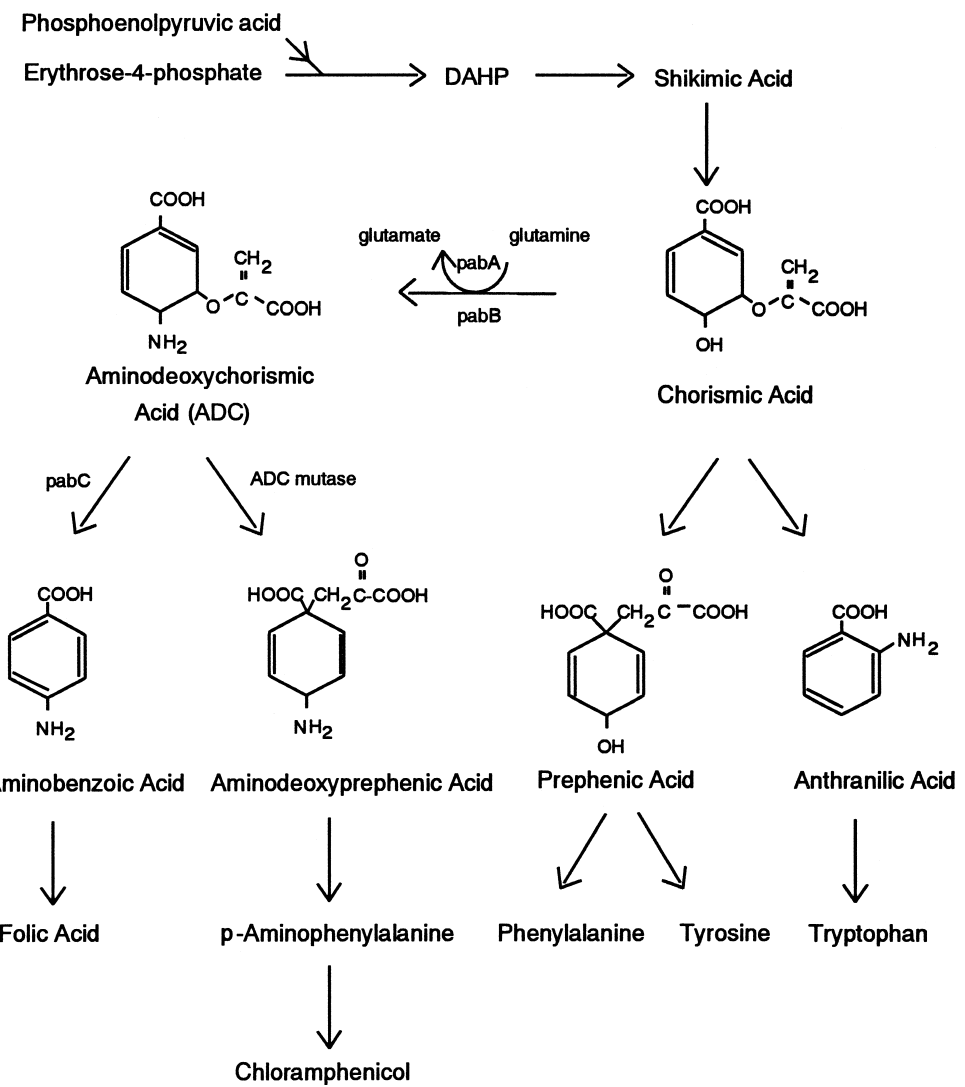

Fig. 2. Shikimate pathway reactions associated with the biosynthesis of primary and secondary aromatic metabolites via chorismic acid in S. venezuelae.

enzyme is presumed to generate 4-amino-4-deoxyprephenic acid (see Fig. 2). The ADC mutase activity parallels that of the chorismate mutase that converts chorismic acid to prephenic acid for phenylalanine and tyrosine synthesis in the primary shikimate pathway. The secondary metabolic pathway proposed here converts chorismic acid to ADC, 4-amino-4-deoxyprephenic acid, PAPA and ultimately $\mathrm{Cm}$. In accord with this hypothesis, further efforts to clone the $\mathrm{Cm}$ biosynthesis cluster were directed to regions of the $S$. venezuelae ISP5230 chromosome flanking pabAB.

\section{METHODS}

Micro-organisms and plasmids. The bacteria, phage and plasmids used are described in Table 1. Streptomyces venezuelae strains were maintained on MYM agar (Stuttard, 1982) supplemented when necessary with one or both of the antibiotics apramycin (Ap; $50 \mu \mathrm{g} \mathrm{ml}^{-1}$ ) and thiostrepton (Ts; $25 \mu \mathrm{g} \mathrm{ml}^{-1}$ ). Minimal (MM) agar used for S. venezuelae plate cultures contained the glucose/asparagine/salts solution of Hopwood (1967), but with maltose instead of glucose. Streptomyces lividans was maintained on K1 medium which contained $\left(\mathrm{l}^{-1}\right)$ : maltose $(10 \mathrm{~g})$, yeast extract $(5 \mathrm{~g}$; Difco), Casamino acids $\left(0 \cdot 2 \mathrm{~g}\right.$; Difco), $\mathrm{K}_{2} \mathrm{HPO}_{4}(0 \cdot 5 \mathrm{~g}), \mathrm{MgSO}_{4} .7 \mathrm{H}_{2} \mathrm{O}$ $(0 \cdot 2 \mathrm{~g}), \mathrm{FeSO}_{4} \cdot 7 \mathrm{H}_{2} \mathrm{O}(0 \cdot 1 \mathrm{~g})$ and agar $(15 \mathrm{~g})$. Cultures of $S$. venezuelae and $S$. lividans were grown as described by Aidoo et al. (1990). For Escherichia coli, LB medium or $2 \times$ YT medium was used (Sambrook et al., 1989).

DNA manipulations. The general procedures described by Sambrook et al. (1989) were used. Plasmid DNA was obtained from E. coli by the alkaline lysis method. To isolate genomic DNA from $S$. venezuelae, the final aqueous solution obtained as described by Hopwood et al. (1985) was extracted with chloroform containing $1 \%(\mathrm{v} / \mathrm{v})$ cetyl trimethylammonium bromide before the DNA was precipitated with an equal volume of 2-propanol. Competent E. coli cells were prepared and transformed as described by Sambrook et al. (1989). Procedures for transforming S. venezuelae ISP5230 were modified (Aidoo et al., 1990) from those developed for $S$. lividans (Hopwood et al., 1985). To avoid restriction by $S$. venezuelae enzymes recognizing methylated DNA (Brown et al., 1996), plasmids were passaged before use through E. coli ET12567, which lacks DNA methylating systems (MacNeil et al., 1992).

For Southern hybridization, restriction digests of genomic DNA electrophoresed in agarose gels were transferred to a positively charged nylon membrane (Qiagen) and probed with a DNA fragment labelled with $\left[{ }^{32} \mathrm{P}\right] \mathrm{dCTP}$ by the random primer method (Amersham Pharmacia Biotech). After hybridization at $65^{\circ} \mathrm{C}$ in a solution containing $5 \times \operatorname{SSPE}(1 \times$ SSPE is $0 \cdot 18 \mathrm{M} \mathrm{NaCl}, 10 \mathrm{mM} \mathrm{Na}{ }_{2} \mathrm{HPO}_{4}$ and $1 \mathrm{mM}$ EDTA, $\mathrm{pH} 7 \cdot 7), 5 \times$ Denhardt's solution, $0.5 \%(\mathrm{w} / \mathrm{v})$ SDS and denatured salmon sperm DNA $\left(100 \mu \mathrm{g} \mathrm{ml}^{-1}\right)$, membranes were washed at $60^{\circ} \mathrm{C}$ with SSPE solutions (twice with $2 \times$, then with $1 \times$ and $0 \cdot 1 \times)$ containing $0 \cdot 1 \%$ SDS. Radioactive fragments were detected with a Bio-Rad CS phosphorimaging screen scanned in a Bio-Rad model GS525 Molecular Imager.

Chromosome walking. A gene bank consisting of genomic DNA fragments from $S$. venezuelae ISP5230 was prepared in $\lambda$ GEM-11 (Facey et al., 1996) and screened for plaques that hybridized with a $\left[{ }^{32} \mathrm{P}\right] \mathrm{dCTP}$-labelled $1.7 \mathrm{~kb}$ Pst $\mathrm{I}-\mathrm{X}$ hoI DNA 
Table 1. Bacterial strains and plasmids

\begin{tabular}{|c|c|c|}
\hline Strains & Genotype/phenotype & Source/reference \\
\hline \multicolumn{3}{|l|}{ S. venezuelae } \\
\hline ISP5230 & Wild-type & Stuttard (1982) \\
\hline VS1050 & $\begin{array}{l}\text { ISP5230 with } 3.5 \mathrm{~kb} \mathrm{NcoI} \text { segment of chromosome upstream of pabAB } \\
\text { replaced by } 1.5 \mathrm{~kb} \mathrm{Am}^{\mathrm{R}} \text { gene }\end{array}$ & This work \\
\hline VS1051 & ISP5230 with $\mathrm{cmlH}$ disrupted by $1.5 \mathrm{~kb} \mathrm{Am}^{\mathrm{R}}$ gene & This work \\
\hline VS1052 & ISP5230 with $\mathrm{cmlP}$ disrupted by $1.5 \mathrm{~kb} \mathrm{Am}^{\mathrm{R}}$ gene & This work \\
\hline VS1053 & ISP5230 with $\mathrm{cmlC}$ disrupted by $1.5 \mathrm{~kb} \mathrm{Am}^{\mathrm{R}}$ gene & This work \\
\hline VS1054 & ISP5230 with $\mathrm{cmlF}$ disrupted by $1.5 \mathrm{~kb} \mathrm{Am}^{\mathrm{R}}$ gene & This work \\
\hline VS1055 & ISP5230 with $\mathrm{cmlJ}$ disrupted by $1.5 \mathrm{~kb} \mathrm{Am}^{\mathrm{R}}$ gene & This work \\
\hline \multicolumn{3}{|c|}{ 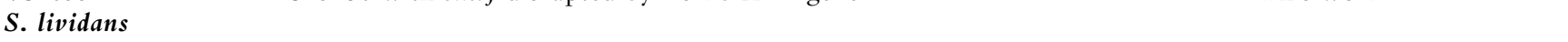 } \\
\hline JG10 & pab-1 str-6 SLP2 ${ }^{-}$SLP3 $^{-}$ & Gil \& Hopwood (1983) \\
\hline \multicolumn{3}{|l|}{ E. coli } \\
\hline $\mathrm{DH} 5 \alpha \mathrm{F}^{\prime} \mathrm{IQ}$ & $\begin{array}{l}\mathrm{F}^{\prime} \phi 80 \mathrm{~d} l a c Z \Delta \mathrm{M} 15 \Delta(\operatorname{lac} Z Y A-\arg F) \text { W169 deoR recA1 endA1 hsdR17 }\left(\mathrm{r}_{\mathrm{k}}^{-} \mathrm{m}_{\mathrm{k}}^{-}\right) \\
\text {supE44 thi-1 gyrA96 relA1 } \mathrm{F}^{\prime} \text { proAB }{ }^{+} \text {lacl }^{\mathrm{q}} Z \Delta \mathrm{M} 15 \text { zzf:: } \operatorname{Tn} 5\left(\mathrm{Km}^{\mathrm{R}}\right)\end{array}$ & Hanahan (1983) \\
\hline ET12567 & dam dcm hsdM & MacNeil et al. (1992) \\
\hline \multicolumn{3}{|l|}{ Plasmids } \\
\hline pBluescript II $(\mathrm{SK}+)$ & E. coli phagemid; $\mathrm{Ap}^{\mathrm{R}}$, lac $Z^{\prime}$ & Stratagene \\
\hline pDQ116 & pIJ41 with $5.65 \mathrm{~kb}$ S. venezuelae insert & Brown et al. (1996) \\
\hline pDQ502 & $\begin{array}{l}\text { pHJL400 with } 5 \cdot 4 \mathrm{~kb} \text { Pst } \mathrm{I}-P s t \mathrm{I} \text { fragment of } S \text {. venezuelae chromosome } \\
\text { including } 3^{\prime} \text {-end of pabAB }\end{array}$ & This work \\
\hline pHJL400 & E. coli-Streptomyces bifunctional vector; $\operatorname{Par}^{-} \mathrm{Ap}^{\mathrm{R}} \mathrm{Ts}^{\mathrm{R}}$ & $\begin{array}{l}\text { Larson \& Hershberger } \\
(1986)\end{array}$ \\
\hline pJV168 & pBluescript II with $7 \cdot 5 \mathrm{~kb}$ S. venezuelae DNA & This work \\
\hline pJV225 & $\begin{array}{l}\text { pBluescript II SK }+ \text { containing } \mathrm{Am}^{\mathrm{R}} \text { gene flanked by multicloning sites with } \\
\text { inverted orientations }\end{array}$ & Chang (1999) \\
\hline pJV326 & E. coli-Streptomyces conjugal bifunctional vector; $\operatorname{Par}^{-} \mathrm{Ap}^{\mathrm{R}} \mathrm{Ts}^{\mathrm{R}}$ & This work \\
\hline pJV351 & pUC18 with a $1.7 \mathrm{~kb} K p n \mathrm{I}-$ Bam HI fragment of S. venezuelae DNA & This work \\
\hline pJV352 & pJV351 with $1.5 \mathrm{~kb} \mathrm{Am}^{\mathrm{R}}$ gene inserted into NotI & This work \\
\hline pJV353 & pJV326 with disrupted $\mathrm{cmlC}$ recloned from pJV352 & This work \\
\hline pJV354 & $\begin{array}{l}\text { pHJL400 with } 7 \cdot 5 \mathrm{~kb} \text { Bam HI-Bam HI fragment of S. venezuelae chromosome } \\
\text { upstream of pabAB }\end{array}$ & This work \\
\hline pJV355 & $\begin{array}{l}\text { pJV354 with } 1.5 \mathrm{~kb} N c o I \text { insert containing } \mathrm{Am}^{\mathrm{R}} \text { gene replacing a } 3.5 \mathrm{~kb} \\
\text { NcoI-NcoI segment }\end{array}$ & This work \\
\hline pJV357 & pKC1218 with $7.5 \mathrm{~kb} \mathrm{BamHI-BamHI}$ insert from S. venezuelae in its BamHI site & This work \\
\hline pJV358 & Same as pJV357 but inserted in opposite orientation & This work \\
\hline pJV368 & $\begin{array}{l}\text { pJV326 with a } 5 \cdot 1 \mathrm{~kb} \text { BamHI-EcoRI fragment containing disrupted ORF8 } \\
\text { from pJV367 }\end{array}$ & This work \\
\hline pJV369 & $\begin{array}{l}\text { pBluescript II SK + containing } 3 \cdot 2 \mathrm{~kb} B g l \mathrm{II}-\text { BamHI fragment from pJV168, } \\
\text { blunted and inserted at SmaI site }\end{array}$ & This work \\
\hline pJV370 & $\begin{array}{l}\text { pJV369 with a } 1.5 \mathrm{~kb} \text { EcoRV fragment containing the } \mathrm{Am}^{\mathrm{R}} \text { gene inserted at } \\
\text { its NruI site }\end{array}$ & This work \\
\hline pJV371 & $\begin{array}{l}\text { pJV326 with a } 4 \cdot 7 \mathrm{~kb} \text { fragment containing disrupted ORF7 in the } \\
\text { XbaI/EcoRI site }\end{array}$ & This work \\
\hline pJV375 & $\begin{array}{l}\text { pBluescript II SK+ with } 3.6 \mathrm{~kb} \text { Pst } \mathrm{I}-\text { Bam HI fragment from pJV168 disrupted } \\
\text { at NcoI with } 1.5 \mathrm{~kb} \mathrm{Am}{ }^{\mathrm{R}} \text { gene from pUC120 }\end{array}$ & This work \\
\hline pJV501 & $\begin{array}{l}\text { pBluescript II SK + with } 1.6 \mathrm{~kb} M l u \mathrm{I}-\text { Bam HI fragment containing ORF9 } \\
\text { from pJV168 }\end{array}$ & This work \\
\hline pJV502 & pUC18 with $1.6 \mathrm{~kb}$ XbaI-KpnI fragment containing ORF9 from pJV501 & This work \\
\hline pJV503 & pJV502 with ORF9 disrupted at its EcoRV site by insertion of the $\mathrm{Am}^{\mathrm{R}}$ gene & This work \\
\hline pJV504 & $\begin{array}{l}\text { pJV326 with a } 3 \cdot 1 \mathrm{~kb} \text { XbaI-EcoRI fragment from pJV503 containing } \\
\text { disrupted ORF9 }\end{array}$ & This work \\
\hline pKC1218 & E. coli vector containing $\mathrm{Am}^{\mathrm{R}}$ and oriT genes & Biermann et al. (1992) \\
\hline pOJ446 & Conjugative vector with oriT between PstI-PstI sites & Biermann et al. (1992) \\
\hline pUC18 & E. coli vector with $l a c Z$ and $A p^{\mathrm{R}}$ & BRL \\
\hline pUC120 & pBluescript with $\mathrm{Am}^{\mathrm{R}}$ gene from pKC462 & Paradkar \& Jensen (1995) \\
\hline pUZ8002 & $\begin{array}{l}\text { E. coli plasmid: RK2 derivative mediating conjugative DNA transfer; } \mathrm{Km}^{\mathrm{R}} \\
\mathrm{Cm}^{\mathrm{R}} \text { Tra }\end{array}$ & $\begin{array}{l}\text { M. S. B. Paget, John Innes } \\
\text { Institute, Norwich }\end{array}$ \\
\hline \multicolumn{3}{|c|}{ ( } \\
\hline GEM-11 & $\lambda$ vector used for library construction & Promega \\
\hline PB1 & $\lambda$ library clone containing $p a b A B$ & This work \\
\hline
\end{tabular}



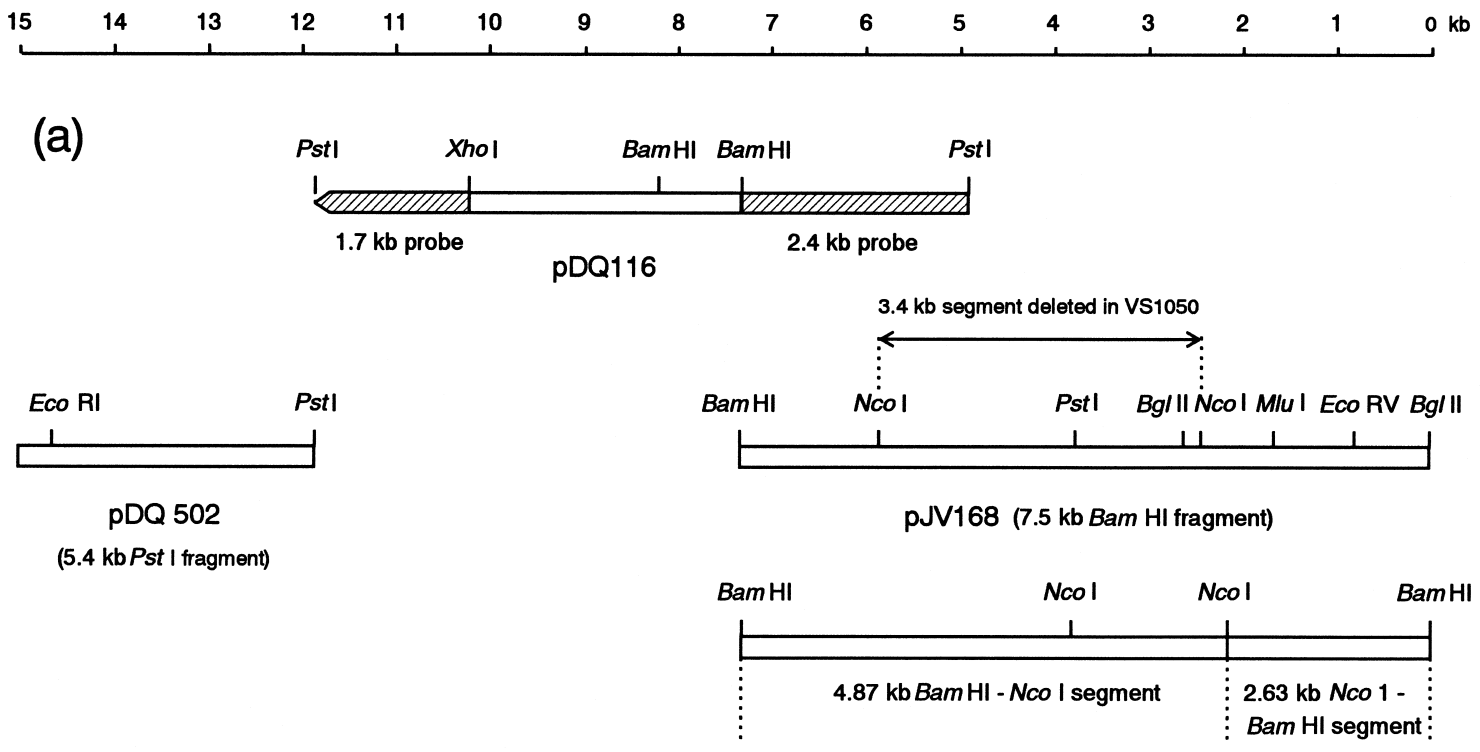

(b)

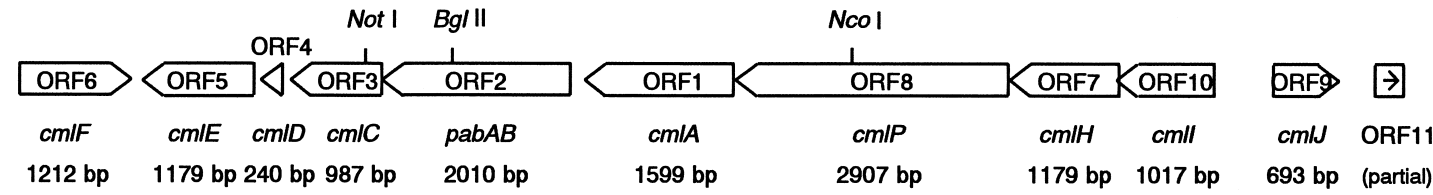

Fig. 3. Restriction map of S. venezuelae chromosomal DNA containing the $\mathrm{Cm}$ biosynthesis gene cluster. (a). Cloned chromosomal DNA in pDQ116 (Brown et al., 1996) extended by chromosome walking. (b). ORFs identified in genomic DNA fragments subcloned from $\lambda$ GEM-11.

fragment isolated from pDQ116 (Brown et al., 1996). The probe contained the $3^{\prime}$ region of $p a b A B$ and an adjacent downstream segment of the S. venezuelae chromosome (Fig. 3). Phages eluted from 10 hybridizing plaques were purified to remove non-hybridizing background and their DNA was isolated. Agarose gel electrophoresis of samples digested with BamHI, XhoI and PstI was examined for fragment patterns that established the homogeneity of the plaque. The gels were blotted on nylon membranes and probed to ensure that the DNA from purified phages included a region hybridizing to the labelled Pst $\mathrm{I}-\mathrm{X}$ hol fragment. Comparing restriction fragments from the DNA of phage containing pabAB identified a representative phage (PB1) with a truncated end-fragment. The fragment was labelled and used as a probe for the next round of plaque hybridizations. Contiguous Pst I fragments from phage PB1 extended cloned chromosomal DNA into the region beyond the $3^{\prime}$ end of $p a b A B$. On the upstream side, the $2 \cdot 4 \mathrm{~kb} B a m \mathrm{HI}-$ Pst I fragment from pDQ116 was used to probe contiguous BamHI fragments of phage PB1 DNA extending cloned chromosomal DNA beyond the $5^{\prime}$ end of $p a b A B$ (see Fig. 3). Through successive digestions of phage PB1 DNA and subsequent walking steps, the cloned region of the $S$. venezuelae chromosome was increased by $15-20 \mathrm{~kb}$ on each side of $p a b A B$.

Construction of a bifunctional vector for conjugal DNA transfer. The $5.8 \mathrm{~kb}$ Streptomyces-E. coli vector pHJL400 (Larson \& Hershberger, 1986) was linearized at its multiple cloning site with PstI and ligated to a $0.76 \mathrm{~kb}$ Pst I fragment containing oriT excised from pOJ446 (Biermann et al., 1992). The ligation mixture was used to transform E. coli DH5 $\alpha$ and the Streptomyces-E. coli bifunctional vector pJV326 containing oriT was isolated.

Conjugal transfer of plasmid DNA from $E$. coli to $S$. venezuelae. Competent cells of E. coli ET12567(pUZ8002) on LB agar supplemented with $\mathrm{Cm}\left(25 \mu \mathrm{g} \mathrm{ml}^{-1}\right)$ and kanamycin $\left(\mathrm{Km} ; 50 \mu \mathrm{g} \mathrm{ml}^{-1}\right)$ were transformed with the plasmid of interest (e.g. pJV354). To transfer the plasmid conjugally from the E. coli transformant to S. venezuelae ISP5230, the two organisms were grown together using culture conditions and protocols based on those described for other streptomycete recipients (Flett et al., 1997; Mazodier et al., 1989). Transconjugant $S$. venezuelae colonies with double-crossovers were selected on MS agar containing nalidixic acid $\left(25 \mu \mathrm{g} \mathrm{ml}^{-1}\right)$ and Am $\left(50 \mu \mathrm{g} \mathrm{ml}^{-1}\right)$, and were patched on MYM agar containing these antibiotics. Spores appeared after $3-4 \mathrm{~d}$ at $30^{\circ} \mathrm{C}$ and were patched in duplicate on MYM agar containing either Am $\left(50 \mu \mathrm{g} \mathrm{ml}^{-1}\right)$ or Am and Ts $\left(25 \mu \mathrm{g} \mathrm{ml}^{-1}\right.$ each $)$.

Construction of $S$. venezuelae deletion mutant VS1050. The mutant was constructed by recloning the $7.5 \mathrm{~kb} \mathrm{BamHI}$ insert from pJV168 in the bifunctional vector pHJL400, giving pJV354. Digestion of pJV354 with NcoI removed an internal $3.4 \mathrm{~kb}$ segment and the residual $\mathrm{NcoI}$ ends were ligated to a $1.5 \mathrm{~kb} \mathrm{~N}$ col cassette containing the $\mathrm{Am}^{\mathrm{R}}$ gene from E. coli (Rao et al., 1983). The resultant plasmid, pJV355, contained a $5.6 \mathrm{~kb} \mathrm{BamHI}$ insert in which the $\mathrm{Am}^{\mathrm{R}}$ gene was flanked on the 
side near ORF1 by $1.5 \mathrm{~kb}$ and on the other side by $2.5 \mathrm{~kb}$ of chromosomal DNA. Recloning the BamHI insert from $\mathrm{pJV} 355$ in the conjugal vector pJV326 and transfer of the vector into S. venezuelae yielded the deletion mutant VS1050, in which homologous recombination had replaced native chromosomal DNA with the vector insert containing the $3.4 \mathrm{~kb}$ deletion. The predicted structures of plasmids and transconjugants were supported by Southern hybridizations with the pJV354 insert and the $\mathrm{Am}^{\mathrm{R}}$ gene as ${ }^{32} \mathrm{P}$-labelled probes.

Gene disruptions. In general, the gene to be disrupted was cloned in an E. coli vector and inactivated by insertion of the $\mathrm{Am}^{\mathrm{R}}$ gene from pUC120 (Paradkar \& Jensen, 1995) or pJV225 (Chang, 1999). The insertionally inactivated gene was then excised from the vector and recloned in the multicloning site of the conjugal vector pJV326. The recombinant conjugal vector was passaged through E. coli ET12567(pUZ8002) to evade streptomycete restriction systems during intergeneric transfer. To disrupt $c m l C$, a $1.7 \mathrm{~kb} \mathrm{KpnI-BamHI}$ fragment of S. venezuelae DNA containing the gene was cloned in pUC18 to give pJV351 and disrupted by insertion into its blunt-ended NotI site of a $1.5 \mathrm{~kb}$ EcoRV fragment carrying the $\mathrm{Am}^{\mathrm{R}}$ gene from pJV225 (Chang, 1999). From this plasmid (pJV352), a $3.2 \mathrm{~kb}$ EcoRI-BamHI fragment containing the disrupted $\mathrm{cmlC}$ was recloned in pJV326 to give pJV353 for conjugal transfer to S. venezuelae ISP5230. To disrupt cmlP, a $3.6 \mathrm{~kb}$ PstI-Bam HI segment was excised from the $7.5 \mathrm{~kb} \mathrm{BamHI}$ insert in pJV168 and recloned in pBluescript II SK + . The resultant plasmid was linearized at its NcoI site and ligated with the $1.5 \mathrm{~kb} \mathrm{NcoI}$ fragment containing the $\mathrm{Am}^{\mathrm{R}}$ gene from pUC120 (Paradkar \& Jensen, 1995) to give pJV375. Digestion of pJV375 with EcoRI and $B a m H I$ generated a $5.1 \mathrm{~kb}$ fragment containing the disrupted $c m l P$ sequence, which was ligated into the multicloning site of pJV326 to give pJV368. Transferring pJV368 from its E. coli host into $S$. venezuelae ISP5230 yielded the disrupted S. venezuelae strain VS1052. To disrupt the putative gene $c m l H$, a $3.2 \mathrm{~kb} \mathrm{BglII-NcoI} \mathrm{segment} \mathrm{of} \mathrm{DNA} \mathrm{containing}$ ORF7 was excised from the $7 \cdot 5 \mathrm{~kb}$ BamHI fragment of $S$. venezuelae DNA in pJV168, blunt-ended and subcloned at SmaI in the multicloning site of pBluescript II SK + . The plasmid obtained (pJV369) was linearized at its NruI site and ligated with the $1.5 \mathrm{~kb} \mathrm{Am}^{\mathrm{R}}$ gene excised with EcoRV from pJV225 (Chang, 1999) to give pJV370. Digestion of pJV370 with EcoRI and $X b a I$ recovered the $4.7 \mathrm{~kb}$ insert containing $\mathrm{cmlH}$ disrupted by the $\mathrm{Am}^{\mathrm{R}}$ gene; ligation of this fragment into the multicloning site of pJV326 gave pJV371. The pJV371 construct was transferred from its E. coli host to $S$. venezuelae ISP5230, generating the transconjugant VS1051. To disrupt $\mathrm{cmlJ}$, the ORF9-containing linear plasmid that remained after deletion of a $4.6 \mathrm{~kb}$ MluI-SalI fragment from pJV168 was blunt-ended and recircularized to give pJV501. The $1.6 \mathrm{~kb}$ $M l u \mathrm{I}-\mathrm{BamHI}$ segment containing ORF9 was retrieved from pJV501 in an XbaI-KpnI fragment and inserted into the multicloning site of pUC18 to give pJV502. The ORF9 sequence in pJV502 was disrupted at its EcoRV site to give pJV503 by introducing the $\mathrm{Am}^{\mathrm{R}}$ gene from pJV225. Insertionally inactivated $\mathrm{cmlJ}$ was excised from the multicloning site of pJV503 as a $3 \cdot 1 \mathrm{~kb}$ EcoRI-XbaI fragment. Ligation of this fragment into pJV326 gave pJV504 for conjugal transfer to $S$. venezuelae ISP5230. Selection with Am yielded the $\mathrm{Am}^{\mathrm{R}} \mathrm{Ts}^{\mathrm{s}}$ transconjugant strain VS1055.

DNA sequencing and sequence analysis. DNA fragments were subcloned in both orientations in pBluescript II SK $(+)$. Overlapping deletions were generated with an ExoIII/S1 nuclease deletion kit (MBI Fermentas) and the religated phagemid DNA was used to transform E. coli DH5 $\alpha$ (BRL). Plasmid DNA from transformants was screened by agarose gel electrophoresis for the desired size and sequenced (ABI 373 automated DNA sequencer). ORFs were detected with both Frameplot 2.3 (Ishikawa \& Hotta, 1999) and the CoDonPREFERENCE program (version 8.1) developed by the Genetics Computer Group (GCG), University of Wisconsin (Devereux et al., 1984). Frameplot 2.3 was accessed electronically (www.nih.go.jp/ jun/cgi-bin/frameplot.pl) to plot the mean $\mathrm{G}+\mathrm{C}$ content of each reading frame and to calculate the $\mathrm{G}+\mathrm{C}$ content at specific locations. The CODONPREFERENCE program was used with the streptomycete codon table of Wright \& Bibb (1992). The BLAST programs of Altschul et al. (1997) were used to search GenBank for proteins with sequence similarity to deduced ORF products. Multiple sequence alignments were generated with the PILEUP program (GCG) and the internet-based CLUSTAL w program (www.clustalw.genome.ad.jp/sit-bin/nph-clustalw).

Estimation of aromatic amines. Filtered supernatants $(5 \mathrm{ml})$ of $S$. venezuelae cultures grown on a shaker (220 r.p.m.) for $7 \mathrm{~d}$ in GI medium at $30{ }^{\circ} \mathrm{C}$ were analysed for aromatic amino and nitro compounds by the procedure of Levine \& Fischbach (1951). The $5 \mathrm{ml}$ sample was applied to a $10 \mathrm{ml}$ column $(1.2 \times 12.5 \mathrm{~cm})$ of Dowex-50 $\times 8(\mathrm{H}+; 200$ mesh particles $)$ and the resin was washed with $20 \mathrm{ml}$ water. Amines retained on the column were eluted with $4 \mathrm{M}$ ammonium hydroxide and collected in $1 \mathrm{ml}$ fractions; samples $(50 \mu \mathrm{l})$ of each absorbed on filter paper for evaporation were sprayed with $0 \cdot 2 \%(\mathrm{w} / \mathrm{v})$ ninhydrin in $n$-butanol/acetic acid $(99: 1, \mathrm{v} / \mathrm{v})$ and heated at $80^{\circ} \mathrm{C}$. Fractions testing positively for amino acids were pooled, evaporated and redissolved in $6.5 \%$ aqueous methanol for HPLC. Analyses by HPLC were performed with a $4.6 \times 100 \mathrm{~mm} \mathrm{C}_{18}$ reverse phase silica gel column (CSC-Sil 80A/ODSZ; $5 \mu \mathrm{m}$ particles) equilibrated with $0 \cdot 1 \mathrm{M}$ sodium acetate buffer, $\mathrm{pH} 4 \cdot 75$. After sample injection $(20 \mu \mathrm{l})$ the eluant gradient was applied (buffer to $50 \%$ methanol/buffer over $4 \mathrm{~min}$, increasing to $100 \%$ methanol over the next $2 \mathrm{~min}$ ). Aromatic amino acids in the eluate were detected at $260 \mathrm{~nm}$. The retention times of PAPA and PAPS were 2.35 and $1.69 \mathrm{~min}$, respectively. The column was re-equilibrated with a gradient from methanol to $100 \%$ buffer over $1 \mathrm{~min}$, followed by buffer alone for $6 \mathrm{~min}$.

Measurement of $\mathrm{Cm}$ production. Strains of $S$. venezuelae ISP5230 were bioassayed against Micrococcus luteus as described by Aidoo et al. (1990). Spores from single colonies on MYM agar were transferred in triplicate to give five equally spaced patches on MYM agar in $9 \mathrm{~cm}$ Petri plates. Spores from the wild-type and a Cm-non-producing mutant were patched as positive and negative controls. After $36-48 \mathrm{~h}$ at $27^{\circ} \mathrm{C}$, a thin layer of GNY soft agar (Malik \& Vining, 1970) seeded with Micrococcus luteus was poured between the patches and after a further $18 \mathrm{~h}$ at $27^{\circ} \mathrm{C}$ the mean width of each inhibition zone was measured. To determine $\mathrm{Cm}$ titres more precisely, shaken cultures were grown in $250 \mathrm{ml}$ Erlenmeyer flasks containing $25 \mathrm{ml}$ glucose/isoleucine medium (Doull et al., 1985). Each culture received a $2 \%(\mathrm{v} / \mathrm{v})$ vegetative inoculum prepared by incubating $S$. venezuelae spores at $30^{\circ} \mathrm{C}$ on a shaker $(220$ r.p.m.) for $24 \mathrm{~h}$ in $10 \mathrm{ml} \mathrm{GNY}$ medium. Production cultures were sampled aseptically 2, 4 and $6 \mathrm{~d}$ after inoculation; the product extracted into ethyl acetate from $5 \mathrm{ml}$ filtered broth was evaporated, taken up in $0.2 \mathrm{ml}$ methanol/water $(3: 1, \mathrm{v} / \mathrm{v})$ and analysed $(20 \mu \mathrm{l}$ injection; $4.6 \times 100 \mathrm{~mm} \mathrm{C}_{18}$ reverse-phase silica-gel column) by HPLC with stepped linear gradients of methanol/water: $0-25$ (v/v) \% for $1 \mathrm{~min}, 25-50 \%$ for $5 \mathrm{~min}, 50-100 \%$ for $1 \mathrm{~min}$, $100 \%$ methanol for $1 \mathrm{~min}$ and then a gradient returning to $100 \%$ water over $1 \mathrm{~min}$. The $\mathrm{Cm}$ titre was estimated by comparing the area of the sharp peak eluted at $6.05 \mathrm{~min}$; 
(detector at $273 \mathrm{~nm}$ ) with areas given by $\mathrm{Cm}$ calibration samples (Brown et al., 1996).

\section{RESULTS}

\section{$\mathrm{Cm}$ biosynthesis genes downstream of pabAB}

The region of the S. venezuelae chromosome adjacent to the $3^{\prime}$ end of $p a b A B$ was present in a $1.7 \mathrm{~kb}$ Pst $\mathrm{I}-\mathrm{X} h o \mathrm{I}$ segment of DNA cloned in pDQ116 (Brown et al., 1996). By subcloning this segment in pBluescript II $(\mathrm{SK}+)$ and deleting internal fragments, the DNA immediately downstream of $p a b A B$ was sequenced from flanking vector primers. Examining the sequence with the Frameplot and CODONPREFERENCE programs detected ORF3 $(\mathrm{cmlC})$, which overlapped the end of pabAB by $1 \mathrm{bp}$ and contained $987 \mathrm{bp}$. Its ATG start codon was separated by $12 \mathrm{bp}$ from the putative RBS AGTGG $(\Delta G$

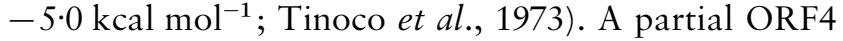
$(\mathrm{cmlD})$ was also present. To obtain the complete sequence of $\mathrm{cmlD}$ and genes further downstream, the $5.4 \mathrm{~kb}$ Pst I fragment adjacent to the $3^{\prime}$ end of pabAB (see Fig. 3) was recovered from phage PB1 DNA, subcloned in pBluescript II SK + to give pDQ502 and sequenced. Frameplot and CODONPREFERENCE analysis of the pDQ502 insert detected three potential ORFs (4-6). That for $\mathrm{cmlD}$ began at a GTG 75 bp downstream of the ORF3 stop codon and was preceded 5 bp upstream by a putative RBS (GGACC; $\Delta G-7 \cdot 3 \mathrm{kcal} \mathrm{mol}^{-1}$ ). An inframe TGA was located only $240 \mathrm{bp}$ downstream of the GTG start codon and was followed 84 bp later by an ATG for the start of ORF5 $(\mathrm{cmlE})$. A plausible RBS (GGAGG; $\Delta G-16.6 \mathrm{kcal} \mathrm{mol}^{-1}$ ) was present $10 \mathrm{nt}$ before the ORF5 start codon and the first in-frame stop codon (TGA) in the sequence defined a $1179 \mathrm{bp}$ gene encoding $392 \mathrm{aa}$. The ORF6 $(\mathrm{cmlF})$ sequence was transcribed in the reverse direction from ORFs 1-5 (see Fig. 3); it spanned $1212 \mathrm{bp}$ and its ATG start codon was preceded with a 9 bp separation by a putative RBS (CGAGG; $\Delta G-13 \cdot 8 \mathrm{kcal} \mathrm{mol}^{-1}$ ). The ORF5 and ORF6 stop codons were separated from the each other by 100 bp DNA. The regions upstream of ORF3, ORF4 and ORF5 did not contain sequences recognizable as -10 or -35 consensus hexamers of E. coli $s^{70}$-type promoters.

Searching GenBank with BLASTP for proteins matching the deduced amino acid sequences of ORFs 3-6 showed a close resemblance between the ORF3 $(\mathrm{cmlC})$ product and PapC from Streptomyces pristinae-spiralis $48 \%$ identical and $59 \%$ similar amino acids in a 319 aa overlap). PapC is a monofunctional prephenate dehydrogenase involved in biosynthesis of the $p$-dimethylaminophenylalanine component of pristinamycin I (Blanc et al., 1997). Consistent with a relationship to prephenate dehydrogenase, the deduced amino acid sequence of ORF3 also resembled (24\% identical and $44 \%$ similar aa in a 251 aa overlap) the $t y r A$ product of Methanococcus jannaschii (Bult et al., 1996). The translated product of ORF4 (CmlD) contained only 79 aa (see Fig. 3), but showed a high overall resemblance (61\% identical amino acids) to PapB, a monofunctional chorismate mutase used by $S$. pristinae-spiralis to biosynthesize the $p$-dimethylaminophenylalanine component of pristinamycin I. The deduced amino acid sequence of ORF5 ( $\mathrm{cmlE}$ ) was markedly similar (41$44 \%$ identity) to class II deoxy-arabino-heptulosonate7-phosphate (DAHP) synthases encoded by genes within clusters for ansamycin biosynthesis in Streptomyces collinus Tu1892 (Chen et al., 1999) and for rifamycin biosynthesis in Amycolatopsis mediterranei (August et al., 1998). Other DAHP synthase genes associated with the biosynthesis of shikimate-derived secondary metabolites have been reported in Pseudomonas aeruginosa, where $\mathrm{PhzC}$ ( $43 \%$ identity to $\mathrm{CmlE}$ ) contributes to pyocyanine biosynthesis (Mavrodi et al., 1998) and in Streptomyces hygroscopicus ATCC 29253, where a DAHP synthase gene accompanies a type-I polyketide synthase gene cluster (Ruan et al., 1997). The deduced amino acid sequence of ORF6 $(\mathrm{cmlF})$ was strikingly similiar to proteins encoded by the $\mathrm{Cm}$ efflux genes cmrA from Rhodococcus erythropolis (Nagy et al., 1997), cmlR from Rhodococcus fascians (Desomer et al., 1992) and $\mathrm{cmlG}$ from S. lividans (Dittrich et al., 1991). It also resembled the product of $\mathrm{cmlV}$, which is located in a region of the S. venezuelae ISP5230 genome distant from pabAB, but containing genes expressing $\mathrm{Cm}$ resistance (Mosher et al., 1995). Topological analysis of the deduced $\mathrm{cmlF}$ product using the TMPRED program of Hofmann \& Stoffel (1993) (http://www.ch.embnet. org/software/TMPRED_form.html) showed 12-13 membrane-spanning domains like those in other $\mathrm{Cm}$ efflux proteins. The similarity suggested a role in exporting $\mathrm{Cm}$ that might be associated with resistance of the producing species to its toxic metabolite.

In separate experiments, $\mathrm{cmlC}$ and $\mathrm{cmlF}$ were disrupted by inserting an E. coli $\mathrm{Am}^{\mathrm{R}}$ gene (Rao et al., 1983) into the cloned sequences. The disrupted $\mathrm{cmlC}$, recloned in the conjugal vector pJV326, was introduced into $S$. venezuelae ISP5230 to generate the transconjugant VS1053. This insertionally inactivated strain grew prototrophically on minimal agar, but produced only $4 \%$ of the wild-type $\mathrm{Cm}$ titre. Cultures of strain VS1054, containing the disrupted $\mathrm{cmlF}$ transconjugant, also grew prototrophically, but unlike VS1053 produced $70-108 \%$ of the wild-type $\mathrm{Cm}$ titre.

\section{$\mathrm{Cm}$ biosynthesis genes upstream of pabAB}

The $S$. venezuelae chromosomal DNA cloned in pDQ116 included $p a b A B$ and upstream DNA containing an incomplete ORF1 that appeared to be co-transcribed with pabAB (Brown et al., 1996; see Fig. 3). The ORF1 sequence was completed by isolating a BamHI fragment of phage PB1 DNA that hybridized with the PstI-BamHI probe from pDQ116. The fragment was subcloned in pBluescript II $(\mathrm{SK}+)$ and sequenced.

(i) $\mathbf{c m I A}$. Analysis of codon usage and third-letter nucleotide bias $(95.9 \mathrm{~mol} \% \mathrm{G}+\mathrm{C})$ in the completed ORF1 sequence indicated that the gene $(\mathrm{cmlA})$ began with an ATG $196 \mathrm{bp}$ upstream of the BamHI site at nt 7281 and contained 1599 bp of DNA encoding 532 aa 


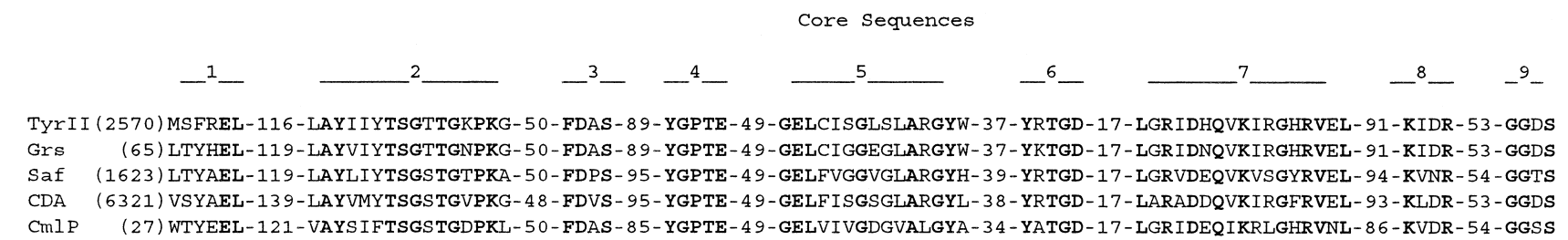

Consensus LT/SYXEL LAYXXYTSGS/TTGXPKG FDXS YGPTE GELXIXGXGV/LARGYL YR/KTGDL GRXDXQVKIRGXRIEL NGKV/L GGD/HS

Fig. 4. Comparison between core sequences in the putative adenylation and thiolation domains of $\mathrm{CmIP}$, and motifs associated with adenylation and thiolation in non-ribosomal peptide synthetases. Core sequences $1-5,7$ and 8 are associated with ATP binding and motif 6 is associated with ATPase activity in the adenylation domain. Core sequence 9 contains the serine of the thiolation domain to which 4'-phosphopantetheine attaches. Bold letters identify invariant amino acids in the five sequences compared. The number in parentheses following the name of the NRPS indicates the position of the first core sequence amino acid in the overall sequence. The numbers interpolated between core sequences give the number of amino acids separating adjacent motifs. Tyrll, tyrocidin synthetase II of Brevibacillus brevis; Grs, gramicidin S synthetase I of Brevibacillus brevis (Hori et al., 1989); Saf, saframycin Mx1 synthetase A of Myxococcus xanthus (Pospiech et al., 1996); CDA, calcium-dependent antibiotic synthetase I of S. coelicolor A3(2) (Chong et al., 1998); $\mathrm{CmIP}$, product of ORF8 in S. venezuelae. The consensus core sequence based on GenBank NRPS sequences is shown below the alignments.

(see Fig. 3). Its ATG start codon was preceded with a $14 \mathrm{bp}$ separation, by a putative RBS (GGAG; $\left.\Delta G-15 \cdot 2 \mathrm{kcal} \mathrm{mol}^{-1}\right)$. Comparison of its deduced amino acid sequence with proteins in the GenBank and S. coelicolor genome databases using BLASTP and TBLASTN (http://www./Projects/S.coelicolor) did not detect any close homologues, although the central portion of $\mathrm{cmlA}$ showed weak resemblance $(30 \%$ identity, $50 \%$ similarity in a 94 aa overlap) to a protein (RomA) from Enterobacter cloacae regulating outermembrane synthesis (Komatsu et al., 1990). A search of the deduced amino acid sequence for possible membrane-binding sites by assessing topology with the TMPRED program of Hofmann \& Stoffel (1993) predicted a strong trans-membrane helix from aa 425 to 447 . Its full extent could not be determined in pDQ116 because the $5^{\prime}$ end of $\mathrm{cmlA}$ was truncated. To investigate the region beyond the $5^{\prime}$ end by chromosome walking, BamHI-digested phage PB1 DNA fragments that hybridized with the $2.4 \mathrm{~kb}$ Bam HI-Pst I fragment of pDQ116 were cloned in pBluescript II SK(+). Sequencing the fragments identified a plasmid (pJV168) that contained a $7.5 \mathrm{~kb} \mathrm{BamHI}$ insert of cloned DNA extending the $5^{\prime}$ end of $\mathrm{cmlA}$. The sequence data did not implicate $\mathrm{cmlA}$ in $\mathrm{Cm}$ biosynthesis, but further examination of the plasmid (see below) indicated that $\mathrm{cml}$ genes were present elsewhere in the cloned DNA fragment carried by pJV168.

(ii) Evidence for $\mathrm{cml}$ genes upstream of $\mathrm{cm} / \mathrm{A}$. To test for $\mathrm{cml}$ genes in pJV168, the plasmid insert was recloned in the conjugal plasmids pJV357 and pJV358, then transferred into a series of previously characterized blocked mutants of S. venezuelae (Doull et al., 1985). Plasmids pJV357 and pJV358 had been constructed in the oriTcontaining vector pKC1218 (Bierman et al., 1992) and carried the pJV168 insert in opposite orientations. The two recombinant plasmids were passaged through $E$. coli ET12567(pUZ8002) before conjugal transfer to the S. venezuelae mutants cml-1, $-2,-3,-4,-6,-8,-10,-11$ and -12 , each of which had been obtained by mutagenesis with nitrosoguanidine and was blocked at a genetically mapped step in Cm production (Doull et al., 1986). Screening transconjugant cultures for restoration of antibiotic biosynthesis showed that $\mathrm{cml}-4$ now produced $48 \mu \mathrm{g} \mathrm{Cm} \mathrm{ml} l^{-1}$, a concentration close to that in the wildtype; none of the other mutations was complemented. Cultures containing pJV358 and pJV357 gave similar $\mathrm{Cm}$ titres, whereas cultures with pJV357 subcloned to delete various portions of the $7.5 \mathrm{~kb}$ insert failed to produce $\mathrm{Cm}$. The results implicated the $7.5 \mathrm{~kb}$ segment of $S$. venezuelae DNA in Cm biosynthesis. Supporting these results, no $\mathrm{Cm}$ was produced by the deletion mutant VS 1050 where an internal $3.4 \mathrm{~kb}$ NcoI fragment had been excised from pJV168 (see Fig. 3) and the construct, recloned in pJV326, had been transferred into S. venezuelae ISP5230 by intergeneric conjugation and allele exchange.

(iii) $\mathrm{cm} / \mathrm{P}$ and $\mathrm{cm} / \mathrm{H}$. A $4.87 \mathrm{~kb}$ BamHI-NcoI segment of the $7.5 \mathrm{~kb}$ DNA insert in pJV168 contained the region of the $S$. venezuelae chromosome near the $5^{\prime}$ end of $\mathrm{cmlA}$ (see Fig. 3). This segment was excised from pJV168 and sequenced (GenBank accession no. AF262220). Frame (Ishikawa \& Hotta, 1999) and codon usage (Devereux et al., 1984) analyses of the nucleotide sequence detected two similarly oriented ORFs (see Fig. 3). The one nearest to $\mathrm{cmlA}$ (ORF8, cmlP) was preceded by a plausible RBS (GGAG; $\Delta G-15 \cdot 2 \mathrm{kcal} \mathrm{mol}^{-1}$ ) and started with a GTG at nt 4185-4187. It ended with a TGA at nt 7078-7080 and the $96.2 \mathrm{~mol} \%$ mean G + C bias in the third codon position was in the range predicted for streptomycete genes. The $2907 \mathrm{bp}$ nucleotide sequence of $\mathrm{cmlP}$ encoded 968 aa which, in a BLASTP search of GenBank, showed marked sequence similarity to typical non-ribosomal peptide synthetases 


\section{CmlP (607) PGAADGDREVLLTGASGFIGGHVLDRLLAAGR \\ SafA3 (2215) LANYLAPSSVLLTGATGYLGAFLLEQLLKRTR \\ Lys2 (964) SAEGKTTINVFVTGVTGFLGSYLAGLLDRSP $*::^{* *}: *$ : *}

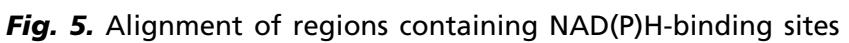
in the amino acid sequences of: CmIP, ORF8 from $S$. venezuelae; SafA3, NRPS from Myxococcus xanthus (Pospiech et al., 1996); Lys2, $\alpha$-aminoadipate reductase of Saccharomyces cerevisiae (Morris \& Jinks-Robertson, 1991). The position in the overall sequence of the first amino acid in each line is given in parentheses. The binding site is overlined; invariant and similar amino acids are marked beneath the alignment with asterisks and colons, respectively.

(NRPSs), including both gramicidin S synthetase I and tyrocidine synthetase II of Brevibacillus brevis (Hori et al., 1989; 32\% overall amino acid identity), saframycin of Myxococcus xanthus (Pospiech et al., 1996) and the calcium-dependent antibiotic (CDA) of Streptomyces coelicolor A3(2) (Chong et al., 1998). A CLUSTAL w alignment of the deduced amino acid sequences of $\mathrm{cmlP}$ and the peptide synthetases revealed motifs associated with predicted functional domains (Fig. 4; Konz \& Marahiel, 1999). Notable in cmlP were highly conserved ATP-binding and ATPase-binding sequences and a phosphopantetheine-binding site. An N-terminal adenylation domain and a central thiolation domain were apparent, whereas there was no indication of the condensation domain that links amino acids of sequential modules and normally completes the three-domain structure of a peptide synthetase (Marahiel et al., 1997). The C-terminal region of cmlP contained an NADHbinding site found in relatively few peptide synthetases (Fig. 5). Such motifs are postulated (Konz \& Marahiel, 1999) to be integral components of reductase domains that terminate peptide-chain elongation. Tailoring domains for epimerization or methylation are notably lacking in $c m l P$ and thus the principal features that define the function of this monomodular NRPS are its amino acid activation (adenylation), thiolation and reductase domains (see Fig. 1).

To disrupt cmlP, the DNA insert in pJV168 was subcloned in pBluescript II SK + and the $\mathrm{Am}^{\mathrm{R}}$ gene from pUC120 (Paradkar \& Jensen, 1995) was inserted at an NcoI site to give pJV375. Ligation of a $5 \cdot 1 \mathrm{~kb}$ fragment containing the disrupted $\mathrm{cmlP}$ sequence into the conjugal vector pJV326 gave $\mathrm{pJV368,} \mathrm{which} \mathrm{after} \mathrm{transfer} \mathrm{from}$ its E. coli host into S. venezuelae ISP5230, integrated into the chromosome. Allele exchange replaced the native $c m l P$ with the disrupted copy, generating the $S$. venezuelae mutant strain VS1052. Cultures of VS1052 accumulated neither $\mathrm{Cm}$ nor PAPA under growth conditions that allowed wild-type S. venezuelae ISP5230 to accumulate $68-74 \mu \mathrm{g} \mathrm{Cm} \mathrm{m}^{-1}$ and $12-15 \mu \mathrm{g}$ PAPA $\mathrm{ml}^{-1}$. By comparison, similarly grown cultures of $S$. venezuelae mutant $\mathrm{cml}-4$, postulated to carry a mutation blocking conversion of PAPA to $\mathrm{Cm}$, accumulated $48 \mu \mathrm{g}$ amino acid $\mathrm{ml}^{-1}$.
The second ORF (ORF7, $\mathrm{cmlH}$ ) in the $4.87 \mathrm{~kb}$ BamHINcoI segment of chromosomal DNA subcloned from the $7.5 \mathrm{~kb}$ insert in pJV168 (see Fig. 3) was presumed to begin with an ATG at nt 3007-3009, although no strong RBS candidate was identified. The first in-frame TGA was at nt 4185-4187, giving an ORF overlapping the start of ORF8 by $13 \mathrm{bp}$ and containing $1179 \mathrm{bp}$ of DNA encoding 392 aa. A BLASTX search of GenBank with the ORF7 sequence did not detect any matching protein sequences. To disrupt the putative $\mathrm{cmlH}$, ORF7 was excised from pJV168 and subcloned in pBluescript II SK + . The subcloned DNA was disrupted by introducing the Am ${ }^{\mathrm{R}}$ gene from pJV225 (Chang, 1999). The $4.7 \mathrm{~kb}$ disrupted copy of $\mathrm{cmlH}$ was recloned in the conjugal vector pJV326 and transferred conjugally from its E. coli host to S. venezuelae ISP5230. Vector integration and allele exchange between the native and disrupted alleles generated the transconjugant VS1051, cultures of which accumulated $13.5 \mu \mathrm{g}$ PAPA ml$l^{-1}$, but no $\mathrm{Cm}$. Cultures of wild-type S. venezuelae ISP5230 grown under the same conditions accumulated $15 \mu \mathrm{g}$ PAPA ml ${ }^{-1}$ and produced $45-55 \mu \mathrm{g} \mathrm{Cm} \mathrm{m}^{-1}$. The results imply that the $\mathrm{cmlH}$ product has a role in the conversion of PAPA to $\mathrm{Cm}$ and indicate that specifically preventing its function does not cause abnormal accumulation of the intermediate.

(iv) cmll and cmlJ. The $2.63 \mathrm{~kb} \mathrm{NcoI-BamHI} \mathrm{segment} \mathrm{of} S$. venezuelae DNA adjoining the $4.87 \mathrm{~kb}$ Bam HI-NcoI DNA segment of the pJV168 insert, and sharing its NcoI site, was subcloned from phage PB1 into pBluescript II $\mathrm{SK}(+)$, giving $\mathrm{pJV} 372$. Analysis of the insert sequence revealed previously undetected ORFs (see Fig. 3). Nearest to ORF7 and similarly oriented, ORF10 (cmlI) began with an ATG at nt 1994, which was preceded $11 \mathrm{bp}$ upstream by a plausible RBS (GGAAG; $\left.\Delta G-7 \cdot 2 \mathrm{kcal} \mathrm{mol}^{-1}\right)$. The downstream ORF10 sequence extended into the adjacent $4.87 \mathrm{~kb}$ BamHI-NcoI segment of pJV168 and terminated with a TGA stop codon at nt 3010-3012. The $1017 \mathrm{bp}$ coding sequence showed a $91.7 \mathrm{~mol} \% \mathrm{G}+\mathrm{C}$ bias in the third codon position, typical of streptomycete genes (Wright \& Bibb, 1992). A gapped BLASTX search of GenBank for sequences resembling that of the 338 aa in the ORF10 product found similarity (29\% identity in a 114 aa overlap) to the product of the chloroplast gene $m p b X$ of Marchantia polymorpha, which belongs in the superfamily containing ATP-binding cassettes for ABC membrane transporters. The coding sequence for ORF9 $(\mathrm{cmlJ})$ in the pJV372 insert was oppositely oriented from that of ORF10 and its GTG start codon (1365-1367) was 627 bp distant from the ORF 10 start codon. The 693 bp ORF9 sequence $(84.8 \mathrm{~mol} \% \mathrm{G}+\mathrm{C}$ bias in the third codon position) terminated with a TGA at nt 675 . Searching GenBank with BLASTP for proteins with sequences similar to that of the translated 229 aa ORF9 sequence detected matches in the family of short-chain oxidoreductases that use $\mathrm{NAD}(\mathrm{P}) \mathrm{H}$ as a cofactor. A CLUSTAL $\mathrm{W}$ alignment of the deduced amino acid sequences of ORF9 with ketoreductases and dehydrogenases of bacterial short-to-medium-chain polyhydroxyalkanoate 
synthases and short-chain fatty acid synthases (Morita \& Okuyama, 1999) demonstrated a conserved $\mathrm{NAD}(\mathrm{P}) \mathrm{H}$ binding site near the $\mathrm{N}$ terminus of each of these sequences. Also conserved in the central region of each sequence was an active site representing the protein family signature.

Frame analyses of the pJV168 DNA sequence at the end furthest from $p a b A B$ detected a partial ORF11 (293 bp), with the same transcriptional orientation as ORF9. The ORF began with an ATG at nt 293-291 and extended beyond the cloned sequence. Using the initial 96 translated amino acids as a query sequence in a BLASTP search of GenBank gave matches with actinomycin synthetase I from Streptomyces chrysomallus (Keller \& Schlumbohm, 1992) and with 4-coumarate coenzyme A ligase from plants. Extending the cloned S. venezuelae chromosomal DNA beyond the 3' end of the pJV168 insert yielded the complete sequence of ORF11 (data not shown). Analysis of this region and a BLAST search of GenBank for proteins with matching sequences indicated that the product of the putative gene $(\mathrm{cmlK})$ closely resembled pristinamycin I synthetase of $S$. pristinae-spiralis (de Crecy-Lagard et al., 1997) and confirmed its similarity to actinomycin synthetase I and a variety of plant 4-coumarate coenzyme A ligases.

\section{DISCUSSION}

Cloning DNA fragments recovered from chromosome walking in regions flanking the ADC synthase gene pabAB has revealed a cluster of genes involved in $\mathrm{Cm}$ biosynthesis. Molecular genetic analysis of the cloned DNA supports earlier biochemical evidence that $\mathrm{Cm}$ biosynthesis begins in a secondary metabolic branch of the shikimate pathway generating PAPA and provides evidence for involvement of a non-ribosomal peptide synthetase in the activation and protection of aromatic amino acid intermediates derived from PAPA. These new insights into the biosynthetic pathway are consistent with evidence from genetic mapping (Vats et al., 1987) that Cm biosynthesis genes in S. venezuelae ISP5230 are clustered in a discrete region of the chromosome. The first specific reaction in $\mathrm{Cm}$ biosynthesis is catalysed by an ADC synthase, encoded by the distinctive secondary metabolic gene pabAB $(\mathrm{cmlB})$ (Brown et al., 1996). The ADC formed in the reaction is channeled towards the formation of aminodeoxyprephenic acid by a monofunctional ADC mutase (see Fig. 2), the gene for which (cmlD; see Fig. 1) has now been located in the $S$. venezuelae ISP5230 chromosome downstream of pabAB. Aminodeoxyprephenic acid may be converted to PAPA by either of two routes. The first would generate $p$-aminophenylpyruvic acid by the action of an enzyme analogous to the prephenate dehydrogenase that catalyses a similar primary metabolic reaction in tyrosine biosynthesis (Pittard, 1996; see Fig. 2). In S. venezuelae the enzyme responsible for the conversion is likely to be the monofunctional cyclohexadienyl dehydrogenase encoded by $\mathrm{cmlC}$. The $\mathrm{CmlC}$ product could subsequently be converted to PAPA by a non-specific aromatic aminotransferase found in $S$. venezuelae (Jones et al., 1978; see Fig. 1). In the alternative route, 4-amino-4-deoxyprephenic acid would be acted upon initially by the aminotransferase to form 4-amino-4-deoxyarogenic acid. This intermediate would be converted to PAPA by the monofunctional cyclohexadienyl dehydrogenase encoded by $\mathrm{cmlC}$. Similar reactions are probably responsible for synthesis of PAPA in S. pristinae-spiralis, where this amino acid is a precursor of pristinamycin I and related peptidolactones (Blanc et al., 1997).

The presence of $\mathrm{cmlE}$ in the $\mathrm{Cm}$ biosynthesis cluster was unexpected. The DAHP synthase encoded by this gene condenses phosphoenolpyruvate and erythrose 4-phosphate, initiating the shikimate pathway; the reaction precedes formation of chorismic acid and the subsequent chorismate branching reaction that begins the specific route to $\mathrm{Cm}$ (Vining \& Westlake, 1984; see Fig. 2). The presence of $\mathrm{cmlE}$ might be accounted for by a role in regulation of the shikimate pathway. In many bacteria, flow of precursors into the pathway is determined by feedback control of isozymic class I DAHP synthases individually sensitive to aromatic amino acids (Pittard, 1996). However, the class II enzyme in S. venezuelae would be expected to show the characteristic properties of plant DAHP synthases, which are activated by tryptophan and not inhibited by aromatic amino acids (Dyer et al., 1990). In S. venezuelae, formation and excretion of $\mathrm{Cm}$ normally begins when the growth rate declines; the presence of a DAHP synthase insensitive to protein digestion products could support the secondary metabolic shikimate pathway activity producing an antibiotic that shields the producer from competitors.

Substantial and similar decreases in $\mathrm{Cm}$ production were caused by disrupting the gene for either ADC synthase $(p a b A B)$ or cyclohexenyl dehydrogenase $(\mathrm{cmlC})$. Since the products of each of these genes participate in the biosynthesis of PAPA, the drop in $\mathrm{Cm}$ production can be attributed to interruption of the supply of shikimate pathway precursors. In contrast to the severe effect of inactivating $p a b A B$ and $c m l C$, the growth of cultures or their ability to produce $\mathrm{Cm}$ was only marginally affected by disrupting $c m l F$, which is postulated to be a Cm efflux gene releasing the antibiotic into the environment and protecting intracellular protein biosynthesis from inhibition. The apparent insensitivity to loss of $\mathrm{cmlF}$ function may reflect the presence in S. venezuelae of other genes mediating $\mathrm{Cm}$ efflux. Mosher et al. (1995) described such a gene in a cloned DNA fragment that also contained a Cm 3'-Ophosphotransferase gene conferring $\mathrm{Cm}$ resistance by inactivating the antibiotic. Chromosome walking experiments (K. A. Aidoo \& L. C. Vining, unpublished) placed this separate set of $\mathrm{Cm}$ resistance genes at least $30 \mathrm{~kb}$ from $p a b A B$ and thus distinct from the autoresistance genes in the $\mathrm{Cm}$ biosynthesis cluster.

Conversion of PAPA to PAPS is a key reaction in Cm biosynthesis; the presence in the $\mathrm{cml}$ cluster of a gene encoding this activity has been inferred from the 
accumulation of PAPA in an S. venezuelae mutant $(\mathrm{cml}$ 4) blocked in $\mathrm{Cm}$ production after treatment with nitrosoguanidine (Doull et al., 1985). Restoration of Cm production in the mutant by introducing the $7.5 \mathrm{~kb}$ fragment of S. venezuelae DNA cloned in pJV168 implies that the cml-4 gene is located in this region of the chromosome. Among sites in the pJV168 insert where the cml-4 function might be located, ORF7 was a potential candidate because $\mathrm{Cm}$ production was lost when the putative $\mathrm{cmlH}$ in ORF7 was disrupted. However, BLAST searches of GenBank and the $S$. coelicolor A3(2) genomic library (http://www. Sanger.ac.uk/Projects/S.coelicolor/) with the translated $\mathrm{cmlH}$ sequence failed to detect homologues from which the function of the gene product could be deduced. Another potential location of the DNA that restored $\mathrm{Cm}$ production in mutant $\mathrm{cml}-4$ was the truncated ORF11 $(\mathrm{cmlK})$ detected at the $3^{\prime}$ end of the chromosomal insert in pJV168. The deduced amino acid sequence of the partial ORF matched proteins (e.g. actinomycin synthetase I; Keller \& Schlumbohm, 1992) that generate adenylated amino acids in the activating domains of enzyme systems. Among these systems may be a PAPA $\beta$-hydroxylase of the type recently characterized in Streptomyces spheroides by Chen \& Walsh (2001). This enzyme system activates tyrosine by forming the adenylate and tethers the aminoacyl component by a thioester linkage to the active site; a cytochrome P450-type monooxygenase then hydroxylates the tethered component to form the $\beta$-hydroxytyrosyl derivative.

In contrast to the absence of matching proteins detected when GenBank was searched with the $\mathrm{cmlH}$ product in BLAST searches, numerous NRPSs were identified in similar searches with the cmlP product as the query sequence. The close similarity of conserved regions in the CmlP adenylation domain to the consensus sequences of adenylation domain motifs implicates an initial reaction activating an amino acid as its adenylate (see Fig. 1). We suggest that PAPS formed from PAPA in the preceding $\beta$-hydroxylation step is the amino acid activated by ATP and tethered to the adenylation domain. The reactive aminoacyl derivative is then transferred to the thiolation domain in $\mathrm{CmlP}$, where it attaches to a peptidyl carrier protein (PCP) containing the conserved serine that forms a thioester with the phosphopantetheinyl group of coenzyme A. A noteworthy feature of the CmlP NRPS is the lack of condensation and thioesterase domains. Their absence implies that the reactive $p$-aminophenylseryl group is not transferred either to a second amino acid by forming a peptide bond or to a terminal substrate from which it is subsequently released by thioesterase activity. A conserved $\mathrm{NAD}(\mathrm{P}) \mathrm{H}$ binding site (Fig. 5) in CmlP suggests the presence of an NRPS reductase domain similar to that described by Pospiech et al. (1996) in SafA3, an NRPS involved with saframycin Mx1 biosynthesis in Myxococcus xanthus. Reductase domains recognized in this and other NRPSs are postulated to terminate peptide synthesis by releasing tethered aminoacyl groups from their thioester linkage by forming linear aldehydes. (Konz \& Marahiel, 1999) In the CmlP NRPS, the reductase domain may reduce the carrier-bound PAPS thioester to $p$-aminophenylserinal and release the product. Alternatively, reductase domain activity may be delayed until the thioester has undergone further modification. Close association of the activated and anchored PAPS thioester with short-lived reactants such as dichloroacetyl-coenzyme A, possibly generated in situ by halogenase-mediated reactions, with the products of intermediary metabolism, may be needed to efficiently introduce the dichloroacetyl substituent into $\mathrm{Cm}$. Association of the aminoacyl thioester with this and other tailoring enzymes, such as a dichloroacetyl $p$-aminophenylserinal reductase and a dichloroacetylp-aminophenylserinol-4-amino oxidase (see Fig. 1), may avoid exposing the intermediates to extraneous catabolic reactions during completion of the $\alpha-N$ dichloroacetyl- $p$-nitrophenylserinol structure of $\mathrm{Cm}$.

\section{ACKNOWLEDGEMENTS}

We are grateful to Dr J. Gil, Oviedo University, for the culture of S. lividans JG10, to Dr C. L. Hershberger, Eli Lilly \& Company, for the vector pHJL400, to Dr A. S. Paradkar, University of Alberta, for the NcoI cassette containing the $\mathrm{Am}^{\mathrm{R}}$ gene and to Zunxue Chang of Dalhousie University for plasmid pJV225 containing the $\mathrm{Am}^{\mathrm{R}}$ gene between sets of inverted multiple cloning sites. This work was supported by the Natural Sciences and Engineering Research Council of Canada.

\section{REFERENCES}

Aidoo, D. A., Barrett, K. \& Vining, L. C. (1990). Plasmid transformation of Streptomyces venezuelae: modified procedures used to introduce the genes for $p$-aminobenzoate synthetase. J Gen Microbiol 136, 657-662.

Altschul, S. F., Madden, T. L., Schaeffer, A. A., Zhang, J., Zhang, Z., Miller, W. \& Lipman, D. J. (1997). Gapped BLAST and PSI-BLAST: a new generation of protein database search programs. Nucleic Acids Res 25, 3389-3402.

August, P. R., Tang, L., Yoon, Y. J. \& 9 other authors (1998). Biosynthesis of the ansamycin antibiotic rifamycin: deductions from the molecular analysis of the rif biosynthetic gene cluster of Amycolatopsis mediterranei S699. Chem Biol 5, 69-79.

Biermann, M., Logan, R., O’Brien, K., Seno, E. T., Rao, R. N. \& Schoner, B. E. (1992). Plasmid cloning vectors for the conjugal transfer of DNA from Escherichia coli to Streptomyces species. Gene 160, 25-31.

Blanc, V., Gil, P., Bamas-Jacques, N. \& 8 other authors (1997). Identification and analysis of genes from Streptomyces pristinaespiralis encoding enzymes involved in the biosynthesis of the 4-dimethylamino-L-phenylalanine precursor of pristinamycin I. Mol Microbiol 23, 191-202.

Brown, M. P., Aidoo, K. A. \& Vining, L. C. (1996). A role for pabAB, a p-aminobenzoate synthase gene of Streptomyces venezuelae ISP5230 in chloramphenicol biosynthesis. Microbiology 142, 1345-1355.

Bult, C. J., White, O., Olsen, G. J. \& 37 other authors (1996). Complete genome sequence of the methanogenic archaeon, Methanococcus jannaschii. Science 273, 1058-1073. 
Chang, Z. (1999). Genes for cysteine biosynthesis and metabolism in Streptomyces venezuelae ISP5230: cloning, sequencing, functional analysis and relevance to chloramphenicol biosynthesis. $\mathrm{PhD}$ thesis, Dalhousie University, Halifax, NS, Canada.

Chen, H. \& Walsh, C. T. (2001). Coumarin formation in novobiocin biosynthesis : $\beta$-hydroxylation of the aminoacyl enzyme tyrosyl-SNovH by a cytochrome P450 NovI. Chem Biol 74, 1-12.

Chen, S., von Bamberg, D., Hale, V., Breuer, M., Hardt, B., Muller, R., Floss, H. G., Reynolds, K. A. \& Leistner, E. (1999). Biosynthesis of ansatrienin (mycotrienin) and naphthomycin. Identification and analysis of two separate biosynthetic gene clusters in Streptomyces collinus Tu1892. Eur J Biochem 261, 98-107.

Chong, P. P., Podmore, S. M., Kieser, H. M., Redenbach, M., Turgay, K., Marahiel, M., Hopwood, D. A. \& Smith, C. P. (1998). Physical identification of a chromosomal locus encoding biosynthetic genes for the lipopeptide calcium-dependent antibiotic (CDA) of Streptomyces coelicolor A3(2). Microbiology 144, 193-199.

de Crecy-Lagard, V., Blanc, V., Gil, P., Naudin, L., Laurenzon, S., Famechon, A., Bamas-Jacques, N., Crouzet, J. \& Thibaut, D. (1997). Pristinamycin I biosynthesis in Streptomyces pristinaespiralis: molecular characterization of the first two structural peptide synthetase genes. J Bacteriol 179, 705-713.

Desomer, J., Vereecke, D., Crespi, M. \& Van Montagu, M. (1992). The plasmid-encoded chloramphenicol-resistance protein of Rhodococcus fascians is homologous to the transmembrane tetracycline efflux proteins. Mol Microbiol 6, 2377-2385.

Devereux, J., Haeberli, P. \& Smithies, O. (1984). A comprehensive set of sequence analysis programs for the VAX. Nucleic Acids Res 12, 387-395.

Dittrich, W., Betzler, M. \& Schrempf, H. (1991). An amplifiable and deletable chloramphenicol-resistance determinant of Streptomyces lividans 1326 encodes a putative transmembrane protein. Mol Microbiol 5, 2789-2797.

Doull, J., Ahmed, Z., Stuttard, C. \& Vining, L. C. (1985). Isolation and characterization of Streptomyces venezuelae mutants blocked in chloramphenicol biosynthesis. J Gen Microbiol 131, 97-104.

Doull, J. L., Vats, S., Chaliciopoulos, M., Stuttard, C., Wong, K. \& Vining, L. C. (1986). Conjugational fertility and location of chloramphenicol biosynthesis genes on the chromosomal linkage map of Streptomyces venezuelae. J Gen Microbiol 132, 1327-1338.

Dyer, W. E., Weaver, L. M., Zhao, J., Kuhn, D. N., Weller, S. C. \& Hermann, K. M. (1990). A cDNA encoding 3-deoxy-Darabino-heptulosonate-7-phosphate synthase from Solanum tuberosum L. J Biol Chem 265, 1608-1614.

Facey, S. J., Gross, F., Vining, L. C., Yang, K. \& van Pee, K. H. (1996). Cloning, sequencing and disruption of a bromoperoxidase-catalase gene in Streptomyces venezuelae. Microbiology 142, 657-665.

Flett, F., Mersinias, V. \& Smith, C.P. (1997). High efficiency intergeneric conjugal transfer of plasmid DNA from Escherichia coli to methyl-DNA-restricting streptomycetes. FEMS Microbiol Lett 155, 223-229.

Gil, J. A. \& Hopwood, D. A. (1983). Cloning and expression of Escherichia coli pabC, the gene encoding aminodeoxychorismate lyase, a pyridoxal phosphate-containing enzyme. J Bacteriol $\mathbf{1 7 4}$, 5317-5323.

Hanahan, D. (1983). Studies on transformation of Escherichia coli with plasmids. J Mol Biol 166, 557-580.

Hofmann, K. \& Stoffel, W. (1993). Tmbase - a database of membrane spanning protein segments. Biol Chem Hoppe-Seyler 347, 166.

Hopwood, D. A. (1967). Genetic analysis and genome structure in Streptomyces coelicolor. Bacteriol Rev 31, 373-403.

Hopwood, D. A., Bibb, M. J., Chater, K. F. \& 7 other authors (1985). Genetic Manipulation of Streptomyces: a Laboratory Manual. Norwich: John Innes Foundation.

Hori, K., Yamamoto, Y., Minetoki, T., Kurotsu, T., Kanda, M., Miura, S., Okamura, K., Furuyama, J. \& Saito, Y. (1989). Molecular cloning and nucleotide sequence of the gramicidin $\mathrm{S}$ synthetase I gene. J Biochem 106, 639-645.

Ishikawa, J. \& Hotta, K. (1999). Frameplot: a new implementation of the frame analysis for predicting protein-coding regions in bacterial DNA with a high G $+\mathrm{C}$ content. FEMS Microbiol Lett 174, 251-253.

Jones, A., Francis, M. M., Vining, L. C. \& Westlake, D. W. S. (1978). Biosynthesis of chloramphenicol in Streptomyces sp. 3022a. Properties of an aminotransferase accepting $p$-aminophenylalanine as a substrate. Can J Microbiol 24, 238-244.

Keller, U. \& Schlumbohm, W. (1992). Purification and characterization of actinomycin synthetase I, a 4-methyl-3-hydroxyanthranilic acid-AMP ligase from Streptomyces chrysomallus. J Biol Chem 267, 11745-11752.

Komatsu, T., Ohta, M., Kido, N., Arakawa, Y., Ito, H., Mizuno, T. \& Kato, N. (1990). Molecular characterization of an Enterobacter cloacae gene (romA) which pleiotropically inhibits the expression of Escherichia coli outer membrane proteins. J Bacteriol 172, 4082-4089.

Konz, D. \& Marahiel, M. A. (1999). How do peptide synthetases generate structural diversity? Chem Biol 6, R39-R48.

Larson, J. L. \& Hershberger, C. L. (1986). The minimal replicon of a streptomycete plasmid produces an ultrahigh level of plasmid DNA. Plasmid 15, 199-209.

Levine, J. \& Fischbach, H. (1951). The chemical determination of chloramphenicol in biological materials. Antibiot Chemother 1, 59-62.

MacNeil, D. J., Gewain, K. M., Rudy, C. L., Dezeny, G., Gibbons, P. H. \& MacNeil, T. (1992). Analysis of Streptomyces avermitilis genes required for avermectin biosynthesis utilizing a novel integration vector. Gene 111, 61-68.

Malik, V. S. \& Vining, L. C. (1970). Metabolism of chloramphenicol by the producing organism. Can J Microbiol 16, 173-179.

Marahiel, M. A., Stachelhaus, T. \& Mootz, H. D. (1997). Modular peptide synthetases involved in nonribosomal peptide synthesis. Chem Rev 97, 2651-2673.

Mavrodi, D. V., Ksenzenko, V. N., Bonsall, R. F., Cook, R. J., Boronin, A. M. \& Thomashow, L. S. (1998). A seven-gene locus for synthesis of phenazine-1-carboxylic acid by Pseudomonas fluorescens 2-79. J Bacteriol 180, 2541-2548.

Mazodier, P., Petter, R. \& Thompson, C. (1989). Intergeneric conjugation between Escherichia coli and Streptomyces species. I Bacteriol 171, 3583-3585.

Morita, N. \& Okuyama, H. (1999). Cloning and sequencing of clustered genes involved in fatty acid biosynthesis from docosahexaenoic acid-producing bacterium Vibrio marinus strain MP-1. Biotechnol Lett 21, 641-646.

Morris, M. E. \& Jinks-Robertson, S. (1991). Nucleotide sequence of the LYS2 gene of Saccharomyces cerevisiae: homology to Bacillus brevis tyrocidine synthetase I. Gene 98, 141-145.

Mosher, R. H., Camp, D. J., Yang, K., Brown, M. P., Shaw, W. V. \& 
Vining, L. C. (1995). Inactivation of chloramphenicol by $\mathrm{O}-$ phosphorylation. J Biol Chem 270, 27000-27006.

Nagy, I., Schoofs, G., Vanderleyden, J. \& De Mot, R. (1997). Transposition of the IS21-related element IS1415 in Rhodococcus erythropolis. J Bacteriol 179, 4635-4638.

Nichols, B.P., Seibold, A. M. \& Doktor, S. Z. (1989). paraAminobenzoate biosynthesis from chorismate occurs in two steps. J Biol Chem 264, 8597-8601.

Paradkar, A. S. \& Jensen, S. E. (1995). Functional analysis of the gene encoding the clavaminate synthase 2 isoenzyme involved in clavulanic acid biosynthesis in Streptomyces clavuligerus. J Bacteriol 177, 1307-1314.

Pittard, A. J. (1996). Biosynthesis of aromatic amino acids. In Escherichia coli and Salmonella typhimurium: Cellular and Molecular Biology, pp. 458-484. Edited by F. C. Neidhardt, R. Curtiss III, J. L. Ingraham, E. C. C. Lin, K. Brooks Law, B. Magasanik, W. S. Reznikoff, M. Riley, M. Schaechter \& H. E. Umbarger. Washington, DC: American Society for Microbiology.

Pospiech, A., Bietenhader, J. \& Schupp, T. (1996). Two multifunctional peptide synthetases and an $O$-methyltransferase are involved in biosynthesis of the DNA-binding antibiotic and antitumour agent saframycin Mx1 from Myxococcus xanthus. Microbiology 142, 741-746.

Rao, R. N., Allen, N. E., Hobbs, J. N., Jr, Alborn, W. E., Jr, Kirst, H. A. \& Paschal, J. W. (1983). Genetic and enzymatic basis for hygromycin B resistance in E. coli. Antimicrob Agents Chemother 24, 689-695.

Ruan, X., Stassi, D., Lax, S. A. \& Katz, L. (1997). A second type-I PKS gene cluster isolated from ATCC 29253, a rapamycinproducing strain. Gene 203, 1-9.

Sambrook, J., Fritsch, E. F. \& Maniatis, T. (1989). Molecular Cloning: a Laboratory Manual, 2nd edn. Cold Spring Harbor, NY: Cold Spring Harbor Laboratory.
Slock, J., Stahly, D. P., Han, C.-Y., Six, E. W. \& Crawford, I. P. (1990). An apparent Bacillus subtilis folic acid biosynthetic operon containing $p a b$, an amphibolic $\operatorname{trp} G$ gene, a third gene required for synthesis of para-aminobenzoic acid and the dihydropteroate synthetase gene. J Bacteriol 172, 7211-7226.

Stuttard, C. (1982). Temperate phages of Streptomyces venezuelae: lysogeny and host specificity shown by SV1 and SV2. J Gen Microbiol 128, 115-121.

Teng, C. Y., Ganem, B., Doktor, S., Nichols, B. P., Bhatnagar, R. K. \& Vining, L. C. (1985). Total biosynthesis of 4-amino-4deoxychorismic acid: a key intermediate in the biosynthesis of $p$ aminobenzoic acid and L-p-aminophenylalanine. J Am Chem Soc 107, 5008-5009.

Tinoco, I., Jr, Borer, P. N., Dengler, B., Levine, M. D., Uhlenbeck, O. C., Crothers, D. M. \& Gralla, J. (1973). Improved estimation of secondary structure in ribonucleic acids. Nature New Biol 246, $40-41$.

Vats, S., Stuttard, C. \& Vining, L. C. (1987). Transductional analysis of chloramphenicol biosynthesis genes in Streptomyces venezuelae. J Bacteriol 169, 3809-3813.

Vining, L. C. \& Stuttard, C. (1994). Chloramphenicol. In Genetics and Biochemistry of Antibiotic Production, pp. 505-530. Edited by L. C. Vining \& C. Stuttard. Boston: Butterworth-Heinemann.

Vining, L. C. \& Westlake, D. W. S. (1984). Chloramphenicol: properties, biosynthesis and fermentation. In Biotechnology of Industrial Antibiotics, pp. 387-411. Edited by S. J. Vandamme. New York \& Basel: Marcel Dekker.

Wright, F. \& Bibb, M. J. (1992). Codon usage in the G + C-rich Streptomyces genome. Gene 113, 55-65.

Received 26 March 2001; revised 6 June 2001; accepted 18 June 2001. 